Article

\title{
Nisin as a Novel Feed Additive: The Effects on Gut Microbial Modulation and Activity, Histological Parameters, and Growth Performance of Broiler Chickens
}

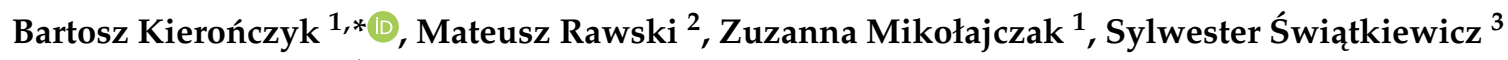 \\ and Damian Józefiak ${ }^{1}$ \\ 1 Department of Animal Nutrition, Poznań University of Life Sciences, Wołyńska 33, 60-637 Poznań, Poland; \\ zuzanna.mikolajczak@up.poznan.pl (Z.M.); damian.jozefiak@up.poznan.pl (D.J.) \\ 2 Division of Inland Fisheries and Aquaculture, Institute of Zoology, Poznań University of Life Sciences, \\ Wojska Polskiego 71c, 60-625 Poznań, Poland; mateusz.rawski@up.poznan.pl \\ 3 Department of Animal Nutrition Physiology, National Research Institute of Animal Production, \\ 32-083 Balice, Poland; s.swiatkiewicz@izoo.krakow.pl \\ * Correspondence: bartosz.kieronczyk@up.poznan.pl; Tel.: +48-618-487-222
}

Received: 13 December 2019; Accepted: 6 January 2020; Published: 8 January 2020

check for updates

Simple Summary: In an era with an increasing number of antibiotic-resistant bacteria strains, there is a need to find a novel and efficient alternative to the antibiotics commonly used in animal nutrition. As natural proteins synthesized by most known bacteria, bacteriocins are considered future candidates. To date, nisin (E234), the best-known bacteriocin, is used as a preservative against food-borne pathogens such as Listeria monocytogenes in the food industry. However, there are scarce data about the application of nisin in the diet of livestock, including poultry. In this study, we evaluated the effect of nisin in broiler chicken diets on selected microbial populations, the activities of which are related to gastrointestinal health, growth performance, and gut histomorphology. We found that nisin application positively affects the feed conversion ratio and exerts a similar effect as the ionophore coccidiostat monensin in the case of microbiota modulation. Additionally, nisin supplementation decreased microbial fermentation in the jejunum. No changes in ileal histomorphology or internal organ weights were noted. We conclude that nisin may be considered a natural and safe antimicrobial agent and growth promoter in broiler chicken nutrition.

\begin{abstract}
Two independent experiments were performed to evaluate the effect of nisin alone or with monensin on gut microbiota, gut microbial activities, and histomorphology (exp 1) and the effect of nisin application in a dose-response manner on the growth performance of broiler chickens (exp 2). A total of 900 one-day-old female Ross 308 chicks (400, exp 1; 500, exp 2) were randomly distributed to four groups (exp 1; 10 replicate pens per treatment with 10 birds each), i.e., NA, no additives; MON, monensin (100 ppm); NIS, nisin (2700 IU/kg diet); and MON + NIS, a mixture of monensin (100 ppm) and nisin (2700 IU/kg diet); or 5 treatments (exp 2), NA, no additives; NIS 100 , nisin (100 IU/kg diet); $\mathrm{NIS}_{200}$, nisin (200 IU/kg diet); NIS 400 , nisin (400 IU/kg diet); and NIS 800 , nisin (800 IU/kg diet). Nisin supplementation positively affected the microbiota of the gut by reducing potentially pathogenic bacterial populations in the jejunum and ceca. The bacterial fermentation in the jejunum was significantly lowered by nisin addition. The addition of nisin from 100 IU to 800 IU decreased the FCR value over the entire experimental period. According to the results, nisin can be considered a natural dietary supplement for broiler chickens.
\end{abstract}


Keywords: bacteriocins; nisin; E234; monensin; feed additive; broiler chicken; performance; microbiota; bacterial fermentation; histomorphology

\section{Introduction}

Nisin (E234) is one of the most examined bacteriocins used as an inhibitory agent of potentially pathogenic bacteria that proliferate in the food industry [1-3]. Bacteriocins are relatively small antimicrobial peptides ribosomally synthesized by most known bacteria, e.g., Firmicutes, Bacteroidetes, Actinobacteria, and Proteobacteria [4]. These substances have activity against both Gram-positive and Gram-negative bacteria, depending on the producing strain [5]. Thus, bacteriocins may be considered novel alternatives for antibiotics and innovative cures in human medicine, as well as veterinary science [6,7]. Nisin $(3.5 \mathrm{kDa})$ is produced by some Lactococcus lactis subsp. lactis strains and, as a protein compound, comprises 34 amino acid residues [8]. Its antimicrobial properties consist of permeabilization of the bacterial cell membrane by pore formation, leading to leakage of cellular content and disruption of the cell, preventing growth [9]. The U.S. Food and Drug Administration notes that nisin is 'generally recognized as safe' (GRAS status; 53 FR 11247), and the European Union approved the usage of nisin as a food additive-E234 (83/463/EEC) [10,11]. The European Food Safety Authority (EFSA) claimed that nisin is digested by protolithic enzymes such as pepsin and trypsin, while other authors mentioned that chymotrypsin, pancreatin, and carboxypeptidases in the gastrointestinal tract (GIT) environment can degrade nisin [12,13]. Therefore, in the literature, it is often assumed that the antibacterial function of this compound is fully eliminated because of protolithic enzymes, and that the compound does not have any impact on the GIT microbiome [14]. In contrast, it is well documented that the use of nisin encapsulated with lipid or bacteriocin without any protection layer may improve the growth of broiler chickens and cause positive GIT microbiota modulations at similar levels $[15,16]$. In addition, the ability of nisin to change the microbiota was also observed in mice, rats, rabbits, and ruminants [17-20]. This is in agreement with the results of an in vitro study that showed that partially digested nisin may maintain its activity against pathogenic bacteria; however, the length of the peptide chain has a crucial effect on bacterial growth inhibition [21,22]. Furthermore, according to the available literature, data about the addition of effective levels of bacteriocins, including nisin, as a feed additive on the productivity parameters and microbial changes in the GIT, with an emphasis on pathogen inhibition, are lacking. To date, only Józefiak et al. [23] have presented the influence of various nisin level inclusions, i.e., 100, 300, 900, and $2700 \mathrm{IU}$ of nisin/g, supplemented in broiler chicken diets. Otherwise, only a few in vivo experiments have been carried out to evaluate the effect of nisin on poultry productivity $[15,16,24,25]$. Therefore, it should be emphasized that the EFSA recommends the continuation of nisin evaluation as an antimicrobial drug for human or livestock use [26]. Therefore, two independent experiments were carried out on broiler chickens to evaluate the effect of dietary nisin alone or in combination with ionophore coccidiostat monensin on the GIT microbiota, microbial activities, and histomorphology (exp 1). The aim of the second experiment was to investigate the effect of relatively small amounts of nisin on growth performance in a dose-response manner.

\section{Materials and Methods}

\subsection{Birds and Housing}

All procedures and experiments complied with the guidelines and were approved by the Local Ethics Commission for Experiments on Animals of Poznań University of Life Sciences (Poznań, Poland; no 8/2015) with respect to animal experimentation and care of the animals under study, and all efforts were made to minimize suffering.

Two independent experiments were conducted. The first experiment was a continuation of a previous trial described in Kierończyk et al. [15], in which nisin and monensin were added to broiler 
chicken diets and the effect on growth performance parameters, coefficients of apparent digestibility of nutrients, tibiotarsus chemical composition, and length and weight of selected sections of the gastrointestinal tract was analyzed. In the present work, the effect of nisin and monensin on selected microbial populations and their activity by analyzing the short-chain fatty acids (SCFAs) and pH of digesta was examined. In total, 400 one-day-old female Ross 308 chicks were used and allotted to four groups, with 10 replications (10 birds each). At the end of the first trial (35 days), the birds were slaughtered, eviscerated, and the digesta from the crop, jejunum, and ceca was collected. All details are given in further sections.

The second trial was carried out to investigate the effect of nisin addition in a dose-response manner, i.e., 100 IU, 200 IU, 400 IU, and 800 IU per kg of broiler chicken diet. A total of 500 one-day-old female Ross 308 chicks were randomly distributed to five dietary treatments, with 10 replicate pens per group and 10 birds per pen. The experiment lasted 35 days, the growth performance parameters, i.e., body weight and feed intake (FI), were determined, and the body weight gain (BWG) and feed conversion ratio (FCR) was calculated. The abovementioned variables were obtained at 14 and 35 days of age using analytical scale (NVL5101, OHAUS, Greifensee, Switzerland) with accuracy $\pm 1 \mathrm{~g}$. The housing conditions were the same in both experiments: the birds were kept in floor pens $(1.00 \times 1.00$ m; straw litter) over 35 days; stock density was established at 10 birds per square meter. Additionally, 9000 birds of the same origin (hatchery) were used to imitate the commercial environment production conditions. The closed chicken house was equipped with an artificial light program (fluorescent lights), automatic heaters, and forced ventilation. The birds were given $23 \mathrm{~h}$ of light and $1 \mathrm{~h}$ of dark for the first week, followed by $19 \mathrm{~h}$ of light and $5 \mathrm{~h}$ without from 7 to 21 days of age. From $22-35 \mathrm{~d}$ of age, the lighting system was similar to that of the first week. The light intensity was set at $20 \mathrm{~lx}$ according to the EU directive (2007/43/EC). The temperature inside the building was set up at $32-33^{\circ} \mathrm{C}$ at the beginning of the test and was reduced by $2-3{ }^{\circ} \mathrm{C}$ each week. On the 28 th day, the temperature was set at $21{ }^{\circ} \mathrm{C}$ and was approximately $18^{\circ} \mathrm{C}$ at the end of the experiment. The humidity level was in the range of $50-60 \%$. During the experimentation, the maximum concentration of $\mathrm{CO}_{2}$, as well as $\mathrm{NH}_{3} \mathrm{did}$ not exceed 3000 ppm, and 10 ppm, respectively. The rearing conditions were set up accordingly to AVIAGEN guidelines.

\subsection{Diets and Feeding Program}

The composition of the experimental basal diets is shown in Table 1 . In both trials, the birds were fed ad libitum and had permanent access to drinking water for $35 \mathrm{~d}$. For each feeding period, all diets were calculated to meet or exceed the nutrient requirements recommended by the NRC [27] for broiler chickens. The experimental diets were designed to provoke GIT colonization by Clostridium perfringens via the usage of viscous cereals (wheat and rye), animal dietary fat (pig lard), and fish meal as ingredients [28-30]. The diets were prepared in mash form; all of the raw materials were ground by a disc mill (Skiold A/S, Sæby, Denmark) at $2.5 \mathrm{~mm}$ disc distance and mixed with no heat treatment. The diets were produced in the Piast Pasze feed mill (Lewkowiec, Poland) according to the ISO 9001:2008 procedures. The feed was prepared on a laboratory-scale line equipped with a horizontal double band mixer (Zuptor, Gostyń, Poland) with roller mills (Skiold, Sæby, Denmark). Initial diets were offered to all birds from 1 to $14 \mathrm{~d}$ of age, and grower-finisher diets were offered from 15 to $35 \mathrm{~d}$ of age. No exogenous enzymes were used in the studies. The design of experiment 1 was as follows: NA, control diet with no additives; MON, monensin addition (100 ppm); NIS, nisin preparation (2700 IU/kg diet); and MON + NIS, a mixture of monensin (100 ppm) and nisin (2700 IU/kg diet). In the second trial, no ionophore coccidiostat was used, and the following treatments were applied: NA, control diet with no additives; $\mathrm{NIS}_{100}$, diet with the addition of nisin preparation (100 IU/kg diet); NIS 200 , nisin supplementation (200 IU/kg diet); $\mathrm{NIS}_{400}$, nisin preparation (400 IU/kg diet); and NIS 800 , nisin addition (800 IU/kg diet). 
Table 1. Composition and nutritive value of the basal diets, experiments 1 and 2.

\begin{tabular}{|c|c|c|}
\hline \multirow{2}{*}{ Ingredient, $\mathbf{g} \cdot \mathbf{k g}^{-1}$} & \multicolumn{2}{|c|}{ Diets } \\
\hline & 1-14 d & $15-35 \mathrm{~d}$ \\
\hline Wheat & 468.7 & 487.5 \\
\hline Rye & 100.0 & 100.0 \\
\hline Rapeseed meal 34.0\% & 100.0 & 100.0 \\
\hline Soybean meal $46.8 \%$ & 222.2 & 186.8 \\
\hline Fish meal 64\% & 20.0 & 20.0 \\
\hline Pig lard & 55.7 & 79.8 \\
\hline Vitamin-mineral premix ${ }^{1}$ & 3.0 & 3.0 \\
\hline Dicalcium phosphate & 19.5 & 12.5 \\
\hline Limestone & 1.0 & 1.6 \\
\hline $\mathrm{NaCl}$ & 1.4 & 1.6 \\
\hline $\mathrm{Na}_{2} \mathrm{CO}_{3}$ & 1.5 & 1.0 \\
\hline L-Lysine & 2.4 & 2.1 \\
\hline DL-Methionine & 3.2 & 2.6 \\
\hline L-Threonine & 1.4 & 1.5 \\
\hline \multicolumn{3}{|c|}{ Calculated nutritive value, $\mathrm{g} \cdot \mathrm{kg}^{-1}$} \\
\hline $\operatorname{AME}_{N}(M J / k g)^{2}$ & 12.3 & 13.3 \\
\hline Crude protein & 215.0 & 200.0 \\
\hline Crude fat & 71.0 & 94.8 \\
\hline Crude fiber & 33.3 & 32.3 \\
\hline Calcium & 8.5 & 7.0 \\
\hline Lysine & 12.5 & 11.3 \\
\hline Methionine & 6.1 & 5.4 \\
\hline Methionine + cystine & 3.8 & 3.6 \\
\hline Threonine & 9.9 & 9.0 \\
\hline
\end{tabular}

\footnotetext{
${ }^{1}$ Provided the following per kilogram of diet: vitamin A, $11.166 \mathrm{IU}$; cholecalciferol, $2.500 \mathrm{IU}$; vitamin E, $80 \mathrm{mg}$; menadione, $2.50 \mathrm{mg}$; B12, $0.02 \mathrm{mg}$; folic acid, $1.17 \mathrm{mg}$; choline, $379 \mathrm{mg}$; d-pantothenic acid, $12.50 \mathrm{mg}$; riboflavin, $7.0 \mathrm{mg}$; niacin, $41.67 \mathrm{mg}$; thiamine, $2.17 \mathrm{mg}$; d-biotin, $0.18 \mathrm{mg}$; pyridoxine, $4.0 \mathrm{mg}$; ethoxyquin, $0.09 \mathrm{mg}$; $\mathrm{Mn}\left(\mathrm{MnO}_{2}\right)$, 73 mg; $\mathrm{Zn}(\mathrm{ZnO}), 55 \mathrm{mg} ; \mathrm{Fe}\left(\mathrm{FeSO}_{4}\right), 45 \mathrm{mg} ; \mathrm{Cu}\left(\mathrm{CuSO}_{4}\right), 20 \mathrm{mg} ; \mathrm{I}\left(\mathrm{CaI}_{2} \mathrm{O}_{6}\right), 0.62 \mathrm{mg} ; \mathrm{Se}\left(\mathrm{Na}_{2} \mathrm{SeO}_{3}\right), 0.3 \mathrm{mg}$. ${ }^{2}$ Apparent metabolizable energy corrected to zero nitrogen balance.
}

\subsection{Preparation of Nisin}

Nisin was prepared according to the method elaborated by the Department of Biotechnology and Food Microbiology, Poznań University of Life Sciences, using Lactococcus lactis subsp. lactis (ATCC11454). All details regarding the preparation and concentration analyses of nisin were reported previously by Józefiak et al. [23] and Kierończyk et al. [15].

\subsection{Data and Sample Collection}

At the end of the first experiment (d 35), 10 randomly chosen birds (one broiler chicken from each of 10 replicate pens per treatment) were sacrificed by cervical dislocation to collect material for further analyses. The $\mathrm{pH}$ values of the digesta samples from the crop, jejunum, and ceca were measured immediately after slaughter using a pH meter with combined glass and reference electrode (VWR International, pH $1000 \mathrm{~L}$, Leuven, Belgium). The portion of the jejunal samples was gently squeezed, immediately packed, sealed in sterilized plastic bags, frozen, and stored at $-80{ }^{\circ} \mathrm{C}$ for analysis of the selected microbial populations by fluorescent in situ hybridization (FISH) of single bacterial cells and organic acids. The jejunum was considered to begin at the end of the duodenum and end at Meckel's diverticulum. The ileum was defined as the small intestinal segment caudal to Meckel's diverticulum. Additionally, the ileal tissue (1 cm after Meckel's diverticulum) was collected after evisceration for histomorphology analysis. The selected internal organ weights in relation to body weight (BW; \% BW), i.e., Bursa of Fabricius, spleen, liver, and pancreas, were measured. After slaughter, the abovementioned organs were rinsed in sterile water, drained, weighed using the electronic balance PS 600/C/2 (Radwag, Radom, Poland) precision scales and measured. The measurement was made 
with accuracy to 3 decimals. In the first experiment, the growth performance parameters, i.e., BWG, FI, and FCR, were analyzed on days 14 and 35.

\subsection{Analysis of the Microbial Community and Its Activity}

All details of sample preparation and FISH analyses for bacteria enumeration from jejunal digesta were described by Rawski et al. [31], and Józefiak et al. [23]. The oligonucleotide probes used in this study are presented in Table 2. The concentration of organic acids in the digesta of the various GIT locations was determined by gas chromatography (Model 6890, Hewlett Packard, Agilent Technologies, Nærum, Denmark) according to Canibe et al. [32].

Table 2. Oligonucleotide probes.

\begin{tabular}{ccccc}
\hline Target & Probe & Sequence (5' ${\text { to } \mathbf{3}^{\prime} \text { ) }}$ & References \\
\hline Enterobacteriaceae & Enter1432 & CTT TTG CAA CCC ACT & [33] \\
Bacteroides-Prevotella cluster & Bac303 & CCAATGTGGGGGACCTT & [34] \\
Clostridium leptum subgroup & Clept1240 & GTTTTRTCAACGGCAGTC & [33] & [35] \\
Clostridium coccoides-Eubacterium rectale cluster & Erec482 & GCTTCTTAGTCARGTACCG & [36] \\
Clostridium perfringens & Cperf191 & GTAGTAAGTTGGTTTCCTCG & [37] \\
\hline Lactobacillus sp./Enterococcus sp. & Lab158 & GGTATTAGCAYCTGTTTCCA & \\
\hline
\end{tabular}

\subsection{Histological Analyses}

The histological analysis of ileal samples was performed according to Rawski et al. [31]. Briefly, the ileal samples were fixed immediately in freshly prepared formaldehyde solution (40 g/L of formaldehyde prepared in 0.01 M PBS, $\mathrm{pH}=7.4$ ) and incubated $12 \mathrm{~h}$. Ileal fragments were dehydrated in alcohol dilutions, stowed in xylene, and embedded in paraffin. At the least 10 slides $(5 \mu \mathrm{m})$ per block were stained using haematoxylin and eosin. The obtained material was analyzed under a light microscope (Axiophot, Carl Zeiss, Germany) with $5 \times 5$ magnification. The length of villi was measured from the top of the epithelium villi to the junction with the crypt. In the cross-sections, the lengths of all villi with a complete structure were measured. Destroyed villi were excluded from the trial. Mucosal thickness was determined as the distance between the mucosal epithelium and the muscular layer, and the muscularis was determined as the inner circular and outer longitudinal layers of smooth muscle cells [38]. The measurements were made on 10 serial slides using a micrometer glass master (0.01 mm, PZO, Warsaw, Poland) and treated as the means.

\subsection{Statistical Analysis}

The experiments had a completely randomized design. All data were tested for normal distributions using the Kolmogorov-Smirnov test. An analysis of variance was conducted using Bartlett's test. The significance of differences among groups was determined with Duncan's multiple range test at the significance level of $p<0.05$. The analyses were performed using SAS software (SAS Institute Inc., Cary, NC, USA).

In the first trial, two factorial designs were applied according to the following general model:

$$
Y_{i j}=\mu+\alpha_{i}+\beta_{j}+(\alpha \beta)_{i j}+\delta_{i j}
$$

where $Y_{i j}$ was the observed dependent variable, $\mu$ was the overall mean, $\alpha_{i}$ was the effect of monensin, $\beta_{\mathrm{j}}$ was the effect nisin, $(\alpha \beta)_{\mathrm{ij}}$ was the interaction between monensin and nisin, and $\delta_{\mathrm{ij}}$ was the random error.

In the second experiment, the following general model was used:

$$
Y_{i}=\mu+\alpha_{i}+\delta_{i j}
$$

where $Y_{i}$ is the observed dependent variable, $\mu$ is the overall mean, $\alpha_{i}$ is the effect of nisin, and $\delta_{i j}$ is the random error. 


\section{Results}

\subsection{Experiment 1}

The effect of nisin and monensin on the $\mathrm{pH}$ values of digesta in selected GIT segments is presented in Table 3. No influence of ionophore coccidiostat or bacteriocin addition on the crop digesta $\mathrm{pH}$ was observed $(p>0.05)$. However, the addition of both nisin $(p<0.001)$ and monensin $(p=0.003)$ increased the $\mathrm{pH}$ of jejunal content. The opposite, i.e., decreased $\mathrm{pH}$ values in the ceca, was observed after nisin $(p=0.039)$ and monensin $(p=0.002)$ supplementation.

The selected microbial populations in the jejunal digesta are presented in Table 4 . Interactions among the experimental factors were observed for the total number of bacteria (DAPI; $p<0.001$ ), Enterobacteriaceae $(p<0.001)$, Clostridium perfringens $(p<0.001)$, and Lactobacillus sp./Enterococcus sp. $(p<0.001)$. Addition of monensin or nisin separately reduced the abovementioned groups of bacteria compared to the NA control treatment. However, the highest effect on the concentration of the abovementioned bacteria was observed in the NIS treatment $(p<0.05)$. Only the concentration of Lactobacillus sp./Enterococcus sp. was not affected by the mixture of experimental factors compared to NA. Furthermore, nisin supplementation significantly decreased the number of the Clostridium leptum subgroup $(p<0.001)$ and the Clostridium coccoides-Eubacterium rectale cluster $(p<0.001)$. The main effect of monensin was the reduction in the Clostridium coccoides-Eubacterium rectale cluster $(p=0.002)$. The experimental factors had not effect on the Bacteroides-Prevotella cluster $(p=0.213)$.

The cecal microbial community is shown in Table 5. Nisin addition to the broiler chicken diets decreased Enterobacteriaceae $(p<0.001)$, the Bacteroides-Prevotella cluster $(p<0.001)$, Clostridium perfringens ( $p<0.001)$, Lactobacillus sp./Enterococcus sp. $(p<0.001)$, the Clostridium leptum subgroup $(p<0.001)$, as well as the Clostridium coccoides-Eubacterium rectale cluster $(p<0.001)$, in comparison to the control group (NA). Similar to nisin, monensin also affected $(p<0.05)$ these selected microbial populations. However, no additive or synergistic effect of experimental factors was observed. Interactions between nisin and monensin were observed except for DAPI ( $p=0.468)$. However, both exhibited the greatest effect on the increased $(p<0.05)$ total bacteria count.

The results of the short-chain fatty acid measurements are shown in Tables 6 and 7 . In the case of microbial fermentation in the jejunum (Table 7), nisin application lowered the sum of volatile fatty acids (VFA) $(p=0.007)$, mainly via reducing the acetic acid concentration $(p=0.024)$. There was no effect on the microbial fermentation in the jejunum after monensin application $(p>0.05)$. The opposite effect was noticed in the ceca, where nisin application enhanced $(p=0.050)$ the concentration of acetic acid. The tendency $(p=0.058)$ of increasing VFA was also observed after nisin supplementation. Additionally, monensin addition increased $(p=0.030)$ the butyric acid, as well as iso-valeric acid $(p=0.050)$ content without affecting the final the sum of VFA $(p=0.177)$ in ceca. There was no interaction $(p>0.05)$ between the experimental factors.

Table 8 presents the results of the ileal histomorphometry measurements. No significant interaction $(p>0.05)$, as well as effects of experimental factors $(p>0.05)$ were noticed in the case of villus high, crypt depth, their ratio, mucosa, and muscular layer thickness. 
Table 3. The effect of dietary supplementation of nisin alone or in combination with monensin on the pH value of the crop, jejunal, and cecal content, Experiment 1.

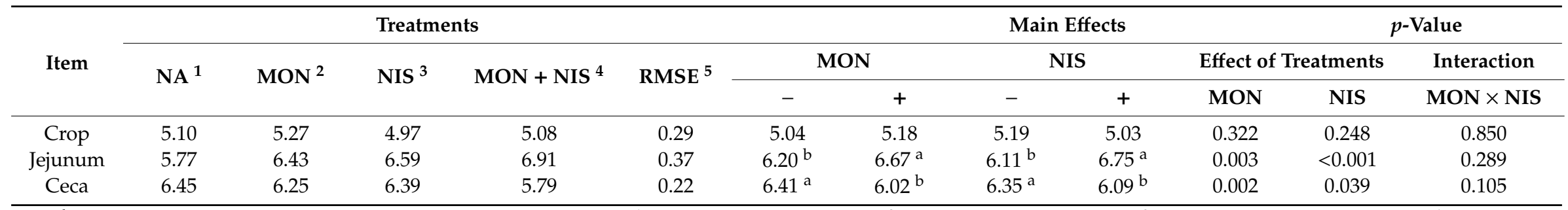

a,b Means not sharing a common superscript differ significantly $(p<0.05) ;{ }^{1}$ control diet with no additives ${ }^{2}$ monensin addition $(100 \mathrm{ppm}) ;{ }^{3}$ nisin preparation $(2700 \mathrm{IU} / \mathrm{kg}$ diet $) ;{ }^{4}$ a mixture

of monensin $(100 \mathrm{ppm})$ and nisin $(2700 \mathrm{IU} / \mathrm{kg}$ diet $){ }^{5}$ root-mean-square error; means represent 10 pens of one chick each (10 replicates).

Table 4. The effect of dietary supplementation of nisin alone or in combination with monensin on selected microbial populations (log CFU/g digesta) in the jejunal content determined by DAPI staining and fluorescent in situ hybridization (FISH), Experiment 1.

\begin{tabular}{|c|c|c|c|c|c|c|c|c|c|c|c|c|}
\hline \multirow{3}{*}{ Item } & \multicolumn{4}{|c|}{ Treatments } & \multirow{3}{*}{ RMSE $^{5}$} & \multicolumn{4}{|c|}{ Main Effects } & \multicolumn{3}{|c|}{$p$-Value } \\
\hline & \multirow{2}{*}{$\mathrm{NA}^{1}$} & \multirow{2}{*}{$\mathrm{MON}^{2}$} & \multirow{2}{*}{$\mathrm{NIS}^{3}$} & \multirow{2}{*}{$\mathrm{MON}+\mathrm{NIS}^{4}$} & & \multicolumn{2}{|c|}{ MON } & \multicolumn{2}{|c|}{ NIS } & \multicolumn{2}{|c|}{ Effect of Treatments } & \multirow{2}{*}{$\begin{array}{c}\text { Interaction } \\
\text { MON } \times \text { NIS }\end{array}$} \\
\hline & & & & & & - & + & - & + & MON & NIS & \\
\hline DAPI & $9.65^{a}$ & $9.39^{b}$ & $9.28^{\mathrm{c}}$ & $9.27^{\mathrm{c}}$ & 0.16 & $9.46^{\mathrm{a}}$ & $9.33^{b}$ & $9.52^{a}$ & $9.28^{b}$ & $<0.001$ & $<0.001$ & $<0.001$ \\
\hline Enterobacteriaceae & $8.78^{\mathrm{a}}$ & $8.52^{b}$ & $8.29^{\mathrm{c}}$ & $8.35^{\mathrm{c}}$ & 0.16 & $8.53^{\mathrm{a}}$ & $8.43^{\mathrm{b}}$ & $8.65^{\mathrm{a}}$ & $8.32^{b}$ & 0.007 & $<0.001$ & $<0.001$ \\
\hline Bacteroides-Prevotella cluster & 8.86 & 8.84 & 8.79 & 8.86 & 0.17 & 8.82 & 8.85 & 8.85 & 8.82 & 0.464 & 0.391 & 0.213 \\
\hline Clostridium perfringens & $8.87^{\mathrm{a}}$ & $8.68^{\mathrm{b}}$ & $8.46^{\mathrm{c}}$ & $8.58^{\mathrm{b}}$ & 0.18 & 8.66 & 8.63 & $8.77^{\mathrm{a}}$ & $8.52^{b}$ & 0.405 & $<0.001$ & $<0.001$ \\
\hline Lactobacillus sp./Enterococcus sp. & $8.99^{\mathrm{a}}$ & $8.77^{b}$ & $8.77^{\mathrm{b}}$ & $8.97^{\mathrm{a}}$ & 0.18 & 8.89 & 8.87 & 8.88 & 8.88 & 0.588 & 0.909 & $<0.001$ \\
\hline Clostridium leptum subgroup & 8.90 & 8.80 & 8.64 & 8.62 & 0.17 & 8.77 & 8.71 & $8.85^{\mathrm{a}}$ & $8.63^{b}$ & 0.129 & $<0.001$ & 0.318 \\
\hline Clostridium coccoides-Eubacterium rectale cluster & 9.14 & 8.98 & 8.80 & 8.73 & 0.16 & $8.97^{\mathrm{a}}$ & $8.85^{\mathrm{b}}$ & $9.06^{\mathrm{a}}$ & $8.77^{\mathrm{b}}$ & 0.002 & $<0.001$ & 0.198 \\
\hline
\end{tabular}

${ }^{\mathrm{a}-\mathrm{c}}$ Means not sharing a common superscript differ significantly $(p<0.05) ;{ }^{1}$ control diet with no additives; ${ }^{2}$ monensin addition (100 ppm); ${ }^{3}$ nisin preparation $\left(2700 \mathrm{IU} / \mathrm{kg}\right.$ diet); ${ }^{4}$ a mixture of monensin $(100 \mathrm{ppm})$ and nisin $\left(2700 \mathrm{IU} / \mathrm{kg}\right.$ diet); ${ }^{5}$ root-mean-square error; means represent 10 pens of one chick each (10 replicates). 
Table 5. The effect of dietary supplementation of nisin alone or in combination with monensin on selected microbial populations (log CFU/g digesta) in the cecal content determined by DAPI staining and fluorescent in situ hybridization (FISH), Experiment 1.

\begin{tabular}{|c|c|c|c|c|c|c|c|c|c|c|c|c|}
\hline \multirow{3}{*}{ Item } & \multicolumn{4}{|c|}{ Treatments } & \multirow{3}{*}{ RMSE $^{5}$} & \multicolumn{4}{|c|}{ Main Effects } & \multicolumn{3}{|c|}{$p$-Value } \\
\hline & \multirow{2}{*}{ NA $^{1}$} & \multirow{2}{*}{$\mathrm{MON}^{2}$} & \multirow{2}{*}{ NIS $^{3}$} & \multirow{2}{*}{ MON + NIS ${ }^{4}$} & & \multicolumn{2}{|c|}{ MON } & \multicolumn{2}{|c|}{ NIS } & \multicolumn{2}{|c|}{ Effect of Treatments } & \multirow{2}{*}{$\frac{\text { Interaction }}{\mathrm{MON} \times \mathrm{NIS}}$} \\
\hline & & & & & & - & + & - & + & MON & NIS & \\
\hline DAPI & 11.01 & 11.07 & 11.06 & 11.17 & 0.14 & $11.0^{\mathrm{b}}$ & $11.11^{\mathrm{a}}$ & $11.04^{\mathrm{b}}$ & $11.12^{\mathrm{a}}$ & 0.012 & 0.011 & 0.468 \\
\hline Enterobacteriaceae & $10.48^{\mathrm{a}}$ & $9.52^{\mathrm{c}}$ & $9.63^{b, c}$ & $9.73^{\mathrm{b}}$ & 0.28 & $10.08^{\mathrm{a}}$ & $9.61^{\mathrm{b}}$ & $9.94^{\text {a }}$ & $9.68^{\mathrm{b}}$ & $<0.001$ & $<0.001$ & $<0.001$ \\
\hline Bacteroides-Prevotella cluster & $10.44^{\mathrm{a}}$ & $9.86^{\mathrm{b}}$ & $9.78^{b}$ & $9.79^{b}$ & 0.23 & $10.14^{a}$ & $9.83^{\mathrm{b}}$ & $10.11^{\mathrm{a}}$ & $9.79^{b}$ & $<0.001$ & $<0.001$ & $<0.001$ \\
\hline Clostridium perfringens & $10.68^{\mathrm{a}}$ & $9.68^{c}$ & $9.66^{c}$ & $9.82^{b}$ & 0.18 & $10.21^{\mathrm{a}}$ & $9.75^{b}$ & $10.13^{a}$ & $9.75^{\mathrm{b}}$ & $<0.001$ & $<0.001$ & $<0.001$ \\
\hline Lactobacillus sp./Enterococcus sp. & $10.73^{a}$ & $9.82^{\mathrm{c}}$ & $9.88^{\mathrm{c}}$ & $10.11^{\mathrm{b}}$ & 0.13 & $10.34^{\mathrm{a}}$ & $9.95^{\mathrm{b}}$ & $10.22^{\mathrm{a}}$ & $10.01^{\mathrm{b}}$ & $<0.001$ & $<0.001$ & $<0.001$ \\
\hline Clostridium leptum subgroup & $10.46^{\mathrm{a}}$ & $9.83^{b, c}$ & $9.71^{\mathrm{b}}$ & $9.86^{\mathrm{b}}$ & 0.23 & $10.11^{\mathrm{a}}$ & $9.84^{\mathrm{b}}$ & $10.11^{\mathrm{a}}$ & $9.80^{\mathrm{b}}$ & $<0.001$ & $<0.001$ & $<0.001$ \\
\hline Clostridium coccoides-Eubacterium rectale cluster & $10.57^{\mathrm{a}}$ & $10.23^{\mathrm{b}}$ & $10.05^{\mathrm{c}}$ & $10.2^{\mathrm{b}}$ & 0.18 & $10.33^{\mathrm{a}}$ & $10.23^{b}$ & $10.38^{a}$ & $10.14^{b}$ & 0.010 & $<0.001$ & $<0.001$ \\
\hline
\end{tabular}

${ }^{\mathrm{a}-\mathrm{c}}$ Means not sharing a common superscript differ significantly $(p<0.05) ;{ }^{1}$ control diet with no additives; ${ }^{2}$ monensin addition $(100 \mathrm{ppm}) ;{ }^{3}$ nisin preparation $\left(2700 \mathrm{IU} / \mathrm{kg}\right.$ diet); ${ }^{4}$ a mixture of monensin (100 ppm) and nisin (2700 IU $/ \mathrm{kg}$ diet); ${ }^{5}$ root-mean-square error; means represent 10 pens of one chick each (10 replicates).

Table 6. The effect of dietary supplementation of nisin alone or in combination with monensin on organic acid concentrations in the jejunal content ( $\mu$ mol/g), Experiment 1.

\begin{tabular}{|c|c|c|c|c|c|c|c|c|c|c|c|c|}
\hline \multirow{3}{*}{ Item } & \multicolumn{4}{|c|}{ Treatments } & \multirow{3}{*}{ RMSE $^{5}$} & \multicolumn{4}{|c|}{ Main Effects } & \multicolumn{3}{|c|}{$p$-Value } \\
\hline & \multirow{2}{*}{$\mathrm{NA}^{1}$} & \multirow{2}{*}{ MON $^{2}$} & \multirow{2}{*}{ NIS $^{3}$} & \multirow{2}{*}{$\mathrm{MON}+\mathrm{NIS}^{4}$} & & \multicolumn{2}{|c|}{ MON } & \multicolumn{2}{|c|}{ NIS } & \multicolumn{2}{|c|}{ Effects of Treatments } & \multirow{2}{*}{$\begin{array}{c}\text { Interaction } \\
\text { MON } \times \text { NIS }\end{array}$} \\
\hline & & & & & & - & + & - & + & MON & NIS & \\
\hline Acetic acid & 2.13 & 1.86 & 1.62 & 1.71 & 0.43 & 1.86 & 1.79 & $1.99^{\mathrm{a}}$ & $1.67^{b}$ & 0.537 & 0.024 & 0.211 \\
\hline Propionic acid & 0.12 & 0.05 & 0.02 & 0.03 & 0.11 & 0.07 & 0.04 & 0.09 & 0.03 & 0.358 & 0.097 & 0.339 \\
\hline Iso-butyric acid & 0.00 & 0.04 & 0.00 & $<0.01$ & 0.04 & 0.00 & 0.02 & 0.02 & $<0.01$ & 0.104 & 0.153 & 0.177 \\
\hline Butyric acid & 0.03 & 0.19 & 0.03 & 0.03 & 0.25 & 0.03 & 0.11 & 0.11 & 0.03 & 0.358 & 0.302 & 0.330 \\
\hline Iso-valeric acid & 0.54 & 0.09 & 0.08 & 0.09 & 0.69 & 0.30 & 0.09 & 0.30 & 0.08 & 0.333 & 0.326 & 0.296 \\
\hline Valeric acid & 0.01 & 0.01 & $<0.01$ & 0.02 & 0.03 & 0.01 & 0.02 & 0.01 & 0.01 & 0.332 & 0.912 & 0.422 \\
\hline Sum of VFA 6 & 2.83 & 2.24 & 1.76 & 1.87 & 0.78 & 2.27 & 2.06 & $2.52^{\mathrm{a}}$ & $1.81^{\mathrm{b}}$ & 0.363 & 0.007 & 0.164 \\
\hline Profile $\mathrm{C} 2{ }^{7}, \%$ & 83.47 & 85.19 & 92.18 & 91.32 & 12.99 & 88.05 & 88.26 & 84.38 & 91.75 & 0.925 & 0.085 & 0.759 \\
\hline Profile C $3^{8}, \%$ & 4.96 & 2.71 & 1.41 & 1.44 & 4.62 & 3.09 & 1.97 & 3.77 & 1.34 & 0.435 & 0.108 & 0.479 \\
\hline Profile $\mathrm{C} 4{ }^{9}, \%$ & 1.12 & 5.95 & 1.69 & 0.41 & 7.24 & 1.42 & 3.70 & 3.66 & 1.57 & 0.345 & 0.372 & 0.281 \\
\hline
\end{tabular}

a,b Means not sharing a common superscript differ significantly $(p<0.05) ;{ }^{1}$ control diet with no additives; ${ }^{2}$ monensin addition $(100 \mathrm{ppm}) ;{ }^{3}$ nisin preparation $\left(2700 \mathrm{IU} / \mathrm{kg}\right.$ diet); ${ }^{4}$ a mixture of monensin $(100 \mathrm{ppm})$ and nisin $\left(2700 \mathrm{IU} / \mathrm{kg}\right.$ diet) ${ }^{5}$ root-mean-square error; ${ }^{6}$ volatile fatty acids; ${ }^{7}$ acetic acid profile; ${ }^{8}$ propionic acid profile; ${ }^{9}$ butyric acid profile; means represent 10 pens of one chick each (10 replicates). 
Table 7. The effect of dietary supplementation of nisin alone or in combination with monensin on organic acid concentrations in the cecal content ( $\mu$ mol/g), Experiment 1.

\begin{tabular}{|c|c|c|c|c|c|c|c|c|c|c|c|c|}
\hline \multirow{3}{*}{ Item } & \multicolumn{4}{|c|}{ Treatments } & \multirow{3}{*}{ RMSE $^{5}$} & \multicolumn{4}{|c|}{ Main Effects } & \multicolumn{3}{|c|}{$p$-Value } \\
\hline & \multirow{2}{*}{ NA $^{1}$} & \multirow{2}{*}{ MON $^{2}$} & \multirow{2}{*}{ NIS $^{3}$} & \multirow{2}{*}{ MON + NIS ${ }^{4}$} & & \multicolumn{2}{|c|}{ MON } & \multicolumn{2}{|c|}{ NIS } & \multicolumn{2}{|c|}{ Effects of Treatments } & \multirow{2}{*}{$\begin{array}{l}\text { Interaction } \\
\text { MON } \times \text { NIS }\end{array}$} \\
\hline & & & & & & - & + & - & + & MON & NIS & \\
\hline Acetic acid & 45.34 & 62.11 & 66.68 & 66.64 & 19.29 & 56.58 & 64.37 & $54.17^{b}$ & $66.66^{a}$ & 0.197 & 0.050 & 0.183 \\
\hline Propionic acid & 4.15 & 4.60 & 5.60 & 4.45 & 2.32 & 4.92 & 4.52 & 4.39 & 5.02 & 0.615 & 0.397 & 0.288 \\
\hline Iso-butyric acid & 0.46 & 0.54 & 0.95 & 0.37 & 0.55 & 0.72 & 0.46 & 0.50 & 0.66 & 0.155 & 0.373 & 0.065 \\
\hline Butyric acid & 10.05 & 15.49 & 14.72 & 18.09 & 6.023 & $12.51^{b}$ & $16.79^{a}$ & 12.91 & 16.40 & 0.030 & 0.079 & 0.595 \\
\hline Iso-valeric acid & 0.74 & 0.67 & 0.78 & 0.60 & 0.18 & $0.77^{\mathrm{a}}$ & $0.64^{\mathrm{b}}$ & 0.70 & 0.70 & 0.050 & 0.977 & 0.367 \\
\hline Valeric acid & 0.94 & 1.05 & 1.07 & 1.02 & 0.24 & 1.02 & 1.04 & 1.01 & 1.05 & 0.720 & 0.587 & 0.321 \\
\hline Sum of VFA 6 & 61.30 & 84.46 & 89.81 & 91.00 & 26.90 & 76.31 & 87.73 & 73.49 & 90.41 & 0.177 & 0.058 & 0.211 \\
\hline Profile $C 2{ }^{7}, \%$ & 57.67 & 73.93 & 74.21 & 66.16 & 19.73 & 66.38 & 70.05 & 66.23 & 70.18 & 0.554 & 0.536 & 0.063 \\
\hline Profile $\mathrm{C} 3^{8}, \%$ & 5.33 & 5.55 & 6.35 & 4.32 & 2.33 & 5.86 & 4.94 & 5.45 & 5.33 & 0.221 & 0.881 & 0.141 \\
\hline Profile $\mathrm{C} 4{ }^{9}, \%$ & 12.54 & 17.80 & 16.33 & 17.69 & 5.25 & 14.54 & 17.74 & 15.31 & 17.01 & 0.061 & 0.317 & 0.254 \\
\hline
\end{tabular}

${ }_{\mathrm{a}, \mathrm{b}}$ Means not sharing a common superscript differ significantly $(p<0.05) ;{ }^{1}$ control diet with no additives; ${ }^{2}$ monensin addition $(100 \mathrm{ppm}) ;{ }^{3}$ nisin preparation $(2700 \mathrm{IU} / \mathrm{kg}$ diet $) ;{ }^{4}$ a mixture of monensin $(100 \mathrm{ppm})$ and nisin $(2700 \mathrm{IU} / \mathrm{kg}$ diet $) ;{ }^{5}$ root-mean-square error; ${ }^{6}$ volatile fatty acids; ${ }^{7}$ acetic acid profile; ${ }^{8}$ propionic acid profile; ${ }^{9}$ butyric acid profile; means represent 10 pens of one chick each (10 replicates).

Table 8. The effect of dietary supplementation of nisin alone or in combination with monensin on ileal histomorphology ( $\mu \mathrm{m}$ ) of broiler chickens, Experiment 1.

\begin{tabular}{|c|c|c|c|c|c|c|c|c|c|c|c|c|}
\hline \multirow{3}{*}{ Item } & \multicolumn{4}{|c|}{ Treatments } & \multirow{3}{*}{ RMSE $^{5}$} & \multicolumn{4}{|c|}{ Main Effects } & \multicolumn{3}{|c|}{$p$-Value } \\
\hline & \multirow{2}{*}{$\mathrm{NA}^{1}$} & \multirow{2}{*}{$\mathrm{MON}^{2}$} & \multirow{2}{*}{ NIS $^{3}$} & \multirow{2}{*}{ MON + NIS ${ }^{4}$} & & \multicolumn{2}{|c|}{ MON } & \multicolumn{2}{|c|}{ NIS } & \multicolumn{2}{|c|}{ Effects of Treatments } & \multirow{2}{*}{$\begin{array}{c}\text { Interaction } \\
\text { MON } \times \text { NIS }\end{array}$} \\
\hline & & & & & & - & + & 2212 & + & MON & NIS & \\
\hline Villus high & 1084 & 1099 & 1045 & 1027 & 129.1 & 1064 & 1063 & 1092 & 1036 & 0.957 & 0.187 & 0.693 \\
\hline Crypt depth & 108 & 112 & 109 & 105 & 13.5 & 109 & 109 & 110 & 107 & 0.976 & 0.491 & 0.429 \\
\hline $\mathrm{V}: \mathrm{C}$ ratio & 10.2 & 10.0 & 9.7 & 9.9 & 1.7 & 10.0 & 10.0 & 10.0 & 9.8 & 0.979 & 0.613 & 0.652 \\
\hline Mucosa thickness & 1198 & 1218 & 1161 & 1140 & 130.8 & 1179 & 1179 & 1208 & 1151 & 0.974 & 0.179 & 0.629 \\
\hline Muscular layer thickness & 164 & 165 & 162 & 159 & 26.1 & 1639 & 162 & 165 & 160 & 0.842 & 0.619 & 0.825 \\
\hline
\end{tabular}

${ }^{1}$ control diet with no additives; ${ }^{2}$ monensin addition (100 ppm); ${ }^{3}$ nisin preparation (2700 IU/kg diet); ${ }^{4}$ a mixture of monensin (100 ppm) and nisin (2700 IU $/ \mathrm{kg}$ diet); ${ }^{5}$ root-mean-square error; means represent 10 pens of one chick each (10 replicates) 


\subsection{Experiment 2}

The growth performance results are shown in Table 9. In general, the addition of nisin ranging from $100 \mathrm{IU}$ to $800 \mathrm{IU}$ per $\mathrm{kg}$ of broiler chicken diet did not significantly affect the BWG or FI $(p>0.05)$. However, the addition of the following activities of nisin, i.e., $100 \mathrm{IU}, 200 \mathrm{IU}$, and $800 \mathrm{IU}$, decreased the FCR values compared to the control group (NA) at $14-35 \mathrm{~d}(p<0.001)$. In terms of the entire experimental period, all proposed activities of bacteriocin lowered the FCR value $(p<0.001)$. In the first two weeks, there was no significant effect of nisin supplementation on the FCR $(p=0.159)$. There were no significant differences between groups $(p>0.05)$ in terms of the selected internal organ weights (Table 10).

Table 9. The effect of dietary supplementation of nisin on the growth performance of broiler chickens, Experiment 2.

\begin{tabular}{|c|c|c|c|c|c|c|c|}
\hline \multirow{2}{*}{ Item } & \multicolumn{5}{|c|}{ Treatment } & \multirow{2}{*}{ RMSE $^{6}$} & \multirow{2}{*}{$p$-Value } \\
\hline & NA $^{1}$ & $\mathrm{NIS}_{100}{ }^{2}$ & $\mathrm{NIS}_{200}{ }^{3}$ & $\mathrm{NIS}_{400}{ }^{4}$ & $\mathrm{NIS}_{800}{ }^{5}$ & & \\
\hline \multicolumn{8}{|c|}{$\mathrm{BWG}^{7}, \mathrm{~g}$} \\
\hline $1-14 \mathrm{~d}$ & 366 & 368 & 366 & 369 & 379 & 2.4 & 0.382 \\
\hline $14-35 \mathrm{~d}$ & 1640 & 1704 & 1745 & 1655 & 1690 & 12.4 & 0.056 \\
\hline $1-35 d$ & 2006 & 2072 & 2111 & 2024 & 2069 & 13.5 & 0.097 \\
\hline \multicolumn{8}{|c|}{$\mathrm{FI}^{8}, \mathrm{~g}$} \\
\hline $1-14 \mathrm{~d}$ & 540 & 541 & 547 & 523 & 539 & 3.2 & 0.191 \\
\hline $14-35 d$ & 2719 & 2729 & 2711 & 2695 & 2729 & 16.1 & 0.964 \\
\hline $1-35 d$ & 3259 & 3269 & 3258 & 3218 & 3268 & 16.9 & 0.877 \\
\hline \multicolumn{8}{|c|}{$\mathrm{FCR}^{9}, \mathrm{~g}: \mathrm{g}$} \\
\hline $1-14 \mathrm{~d}$ & 1.48 & 1.47 & 1.49 & 1.42 & 1.43 & 0.01 & 0.159 \\
\hline $14-35 \mathrm{~d}$ & $1.66^{\mathrm{a}}$ & $1.60^{b}$ & $1.55^{\mathrm{c}}$ & $1.63^{\mathrm{ab}}$ & $1.62^{b}$ & 0.01 & $<0.001$ \\
\hline $1-35 d$ & $1.63^{\mathrm{a}}$ & $1.58^{\mathrm{c}}$ & $1.54^{\mathrm{b}}$ & $1.59^{b}$ & $1.58^{\mathrm{b}}$ & 0.01 & $<0.001$ \\
\hline
\end{tabular}

${ }^{\mathrm{a}-\mathrm{c}}$ Means not sharing a common superscript differ significantly $(p<0.05) ;{ }^{1}$ control diet with no additives; ${ }^{2}$ diet with the addition of nisin preparation (100 IU $/ \mathrm{kg}$ diet); ${ }^{3}$ nisin supplementation (200 IU $/ \mathrm{kg}$ diet); ${ }^{4}$ nisin preparation (400 IU/kg diet); ${ }^{5}$ nisin addition (800 IU $/ \mathrm{kg}$ diet) $;{ }^{6}$ root-mean-square error; ${ }^{7}$ body weight gain; ${ }^{8}$ feed intake; ${ }^{9}$ feed conversion ratio; means represent 10 pens of 10 chicks each.

Table 10. The effect of dietary supplementation of nisin on the selected internal organs of broiler chickens, Experiment 2.

\begin{tabular}{cccccccc}
\hline \multirow{2}{*}{ Item } & \multicolumn{5}{c}{ Treatment } & \multirow{2}{*}{ RMSE $^{\mathbf{6}}$} & $\boldsymbol{p}$-Value \\
\cline { 2 - 5 } & $\mathbf{N A}^{\mathbf{1}}$ & $\mathbf{N I S}_{\mathbf{1 0 0}}{ }^{\mathbf{2}}$ & $\mathbf{N I S}_{\mathbf{2 0 0}}{ }^{\mathbf{3}}$ & $\mathbf{N I S}_{\mathbf{4 0 0}} \mathbf{4}^{\mathbf{4}}$ & $\mathbf{N I S}_{\mathbf{8 0 0}}{ }^{\mathbf{5}}$ & & \\
\hline Bursa of & 0.18 & 0.15 & 0.17 & 0.17 & 0.17 & 0.04 & 0.523 \\
Fabricius & 0.10 & 0.12 & 0.12 & 0.14 & 0.13 & 0.04 & 0.193 \\
Spleen & 0.28 & 0.27 & 0.25 & 0.25 & 0.27 & 0.04 & 0.214 \\
Pancreas & 2.83 & 2.85 & 2.95 & 2.88 & 2.90 & 0.29 & 0.820 \\
Liver & 2.83 &
\end{tabular}

${ }^{1}$ control diet with no additives; ${ }^{2}$ diet with the addition of nisin preparation $(100 \mathrm{IU} / \mathrm{kg}$ diet $){ }^{3}$ nisin supplementation (200 IU $/ \mathrm{kg}$ diet); ${ }^{4}$ nisin preparation (400 IU $\left./ \mathrm{kg} \mathrm{diet)}\right){ }^{5}$ nisin addition (800 IU $/ \mathrm{kg}$ diet); ${ }^{6}$ root-mean-square error; means represent 10 pens of one chicks each (10 replicates).

\section{Discussion}

According to the EFSA report, nisin is considered a novel antimicrobial drug for humans as well as domestic animals, and it is recommended that its mode of action under in vivo conditions be further evaluated [26]. Hitherto, there are a few commercially available products containing nisin that are used to prevent and cure mastitis [39,40]. Furthermore, nisin has been widely examined against Staphylococcus aureus-induced skin infections, dental caries, and apoptosis of cancer cells factor [41-43]. Nisin usage as a food preservative against mainly Listeria monocytogenes is thought of as safe because it 
is degraded by endogenous proteolytic enzymes in the GIT [44,45]. In human nutrition, the average daily intake (ADI) of nisin was updated from $1 \mathrm{mg}$ per $\mathrm{kg}$ of body weight (BW) to $12 \mathrm{mg} / \mathrm{kg}$ BW (unripened cheese) and $25 \mathrm{mg} / \mathrm{kg}$ BW (heat-treated meat products) [26]. In contrast, bacteriocins are forbidden for use in livestock diets, including poultry, and bacteriocins are not registered as feed additives (EU 1831/2003). Surprisingly, nisin is able to maintain its antimicrobial activity after digestion depending on the resulting fragments [21]. This is in agreement with the results of Józefiak et al. [23], where significant changes in the GIT microbiota were noticed by the positive reduction in potentially pathogenic groups of bacteria, i.e., the Bacteroides-Prevotella cluster, and Enterobacteriaceae in the ileum after nisin supplementation. Additionally, Kieronczyk et al. [16] highlighted the positive effect of nisin on the reduction in the proliferation of Clostridium perfringens and Lactobacillus sp./Enterococcus sp. in this segment. The results of the present study confirmed the antimicrobial properties of nisin in both the jejunum and ceca. In addition to previously mentioned microbial populations, nisin has limited the number of Clostridium leptum subgroup, and the Clostridium coccoides-Eubacterium rectale cluster. The positive effects of nisin application in broiler chicken diets on changes in the microbiota consist not only of a reduction in pathogen occurrence in the chicken GIT, but also of lowering the competition for nutrients between bacteria and the host, improving energy utilization by decreasing the number of bacteria from the genera Lactobacillus, Clostridium, and Bacteroides [46,47]. The activity measurements, i.e., $\mathrm{pH}$ and SCFA concentration, were consistent with the microbiology results. The increasing $\mathrm{pH}$ value in the jejunum is a result of the reduction in Lactobacillus sp./Enterococcus sp. population and low acetic acid fermentation, as well as the sum of the VFA. This is in agreement with the results of Józefiak et al. [23], who found that nisin (2700 IU) significantly decreased the total SCFA concentration in the ileum. However, in the present study, the cecum fermentation tended $(p=0.058)$ to increase with increasing acetic acid concentration after nisin addition to the chicken diet, while other authors observed contradicting results. Nevertheless, the lower activity of nisin, i.e., $100 \mathrm{IU}, 300 \mathrm{IU}, 900 \mathrm{IU}$, did not affect the cecum fermentation [23]. In the present study, the effects of nisin on the microbiota fermentation (ileal and cecal) may be explained by its main antimicrobial targeting. It is well documented that bacteriocins inhibit the growth and development of bacteria especially in the case of closely related taxa, i.e., across genera or the same species [48]. Due to this fact, the nisin produced by the L. lactis subsp. lactis may have the main impact on lactic acid bacteria (LAB), thus the microbial fermentation is reduced in the higher GIT segments where they occur as dominant, i.e., the crop $\left(10^{9}\right.$ cells $\left.\mathrm{g}^{-1}\right)$, gizzard $\left(10^{8}\right.$ cells $\left.\mathrm{g}^{-1}\right)$ as well as small intestine $\left(10^{9}-10^{11} \mathrm{~g}\right.$ cells $\mathrm{g}^{-1}$ ) [49-51]. Contrary to the ceca where the LAB populations (Bacillus-Lactobacillus-Streptococcus subdivision) are in minority [52]. The abovementioned mechanism seems to be confirmed by the fact that the fermentation in ceca was not reduced as much as in the upper parts due to the presence of wide spectra of bacterial populations which could be resistant to nisin activity. Additionally, the effect of monensin was noticed by the positive reduction of iso-valeric acid concentration, which is a component of putrefactive SCFA (PSFA). It is well known that PSCFA is related to protein fermentation in the ceca by, e.g., Clostridium perfringens, and Enterobacteriaceae [53,54]. It is in agreement with obtained results, where the proliferation of abovementioned bacteria was inhibited. Moreover, the decreasing number of volatile fatty acid-producing strains in the ceca result in increased concentrations of propionic, acetic, as well as butyric acid [55]. In the current study, only butyric acid fermentation has been enhanced by monensin addition, while the Clostridium leptum subgroup and Clostridium coccoides-Eubacterium rectale cluster were lowered by the coccidiostat. Nevertheless, the increased level of their activity may have a beneficial impact on the GIT microbiota populations [56]. It should be emphasized that nisin exerts a similar mode of action to salinomycin in terms of antimicrobial properties, as well as the growth performance parameters [16,23]. As the present results have shown, the ionophore coccidiostat monensin also has convergent activity with nisin in the case of microbiota modulation. However, no additive or synergistic effect was observed in the selected microbial populations.

There is still a lack of data on the inclusion level or activity of bacteriocins, including nisin, which may be efficiently used as antimicrobial agents, as well as growth promoters in poultry nutrition. 
In terms of broiler chickens, only two bacteriocins, i.e., divercin AS7 and nisin, have been partially examined in terms of their dosage [23,57]. Hitherto, it was mentioned that nisin at high activity (900 IU and $2700 \mathrm{IU}$ ) has shown the most efficient performance in broilers. In general, supplementation of nisin to chicken diets causes increased the BWG and FI, simultaneously decreasing the FCR [23]. However, it should be mentioned that these results are particularly marked in the first rearing period, i.e., until $14 \mathrm{~d}$ of age. This is in agreement with Kieronczyk et al. [16], where the positive effect of nisin on the BWG, FI, and FCR was noticed only in the first period. In contrast to the above, divercin AS7 characterized by even low activity, i.e., $100 \mathrm{AU}, 200 \mathrm{AU}$, and $300 \mathrm{AU}$, positively affected the FCR value of broiler chickens [57]. Additionally, divercin AS7 exerted a similar effect on the BWG and FCR as salinomycin [58]. In the present experiment, the growth performance results revealed a positive role of nisin as a growth promoter. Each dosage of bacteriocin significantly reduced $(p<0.001)$ the FCR value in the last period of the experiment (14-35 d) and throughout the entire trial (1-35 d). Although monensin was not examined as a growth promoter in this study, in the available literature the positive effect of nisin on growth performance results was comparable to that of ionophore coccidiostats, i.e., salinomycin, as well as monensin [15].

Referring to the results of Kierończyk et al. [15], which showed no significant changes in apparent ileal digestibility of crude protein and ether extract after nisin addition, the present study confirmed no detrimental influence on the villus high, crypt depth, mucosa, and muscular layer thickness. The reduction in the length and weight of the duodenum, jejunum, ileum, and cecum have been noted [15]. To date, the histomorphology of the GIT after nisin application was measured only in rabbits, and no effect was observed on the villus surface, height, and crypt depth. Additionally, the application of albusin B, as well as bacteriocin B602, to poultry diets confirmed that these parameters were not affected $[59,60]$.

\section{Conclusions}

The results of the current experiments emphasized that nisin addition to broiler chicken diets may be considered a novel and natural growth promoter that improves feed utilization even at low levels. Moreover, it was confirmed that nisin plays a significant role in the positive modulation of the microbiota of the GIT of broiler chickens via the reduction in the proliferation and populations of potentially pathogenic bacteria, which may negatively alter nutrient utilization. A limitation of bacterial activity was observed in the jejunal digesta, while cecal fermentation tended to be enhanced. Additionally, a positive interaction between bacteriocin nisin and ionophore coccidiostat-monensin was observed without any additive or synergetic effect. The findings of the present study suggest that nisin exerts a mode of action similar to that of monensin in the scope of antimicrobial properties. Additional studies in terms of the evaluation of anticoccidial properties of nisin are recommended.

Author Contributions: Conceptualization, B.K. and D.J.; Formal analysis, B.K. and Z.M.; Investigation, B.K., M.R. and D.J.; Methodology, B.K., M.R. and D.J.; Project administration, B.K.; Resources, B.K.; Supervision, B.K., M.R., S.Ś. and D.J.; Writing—original draft, B.K.; Writing—review and editing, B.K., M.R., S.Ś. and D.J. All authors have read and agreed to the published version of the manuscript.

Funding: This study was partially supported by the following grants: PRELUDIUM No. UMO-2014/15/N/NZ9/ 01529, financed by the National Science Center (Poland), Grant No. 507.533.10 (2017) of the Young Researcher Program of the Faculty of Veterinary Medicine and Animal Science Poznań University of Life Sciences, Poland financed by the Polish Ministry of Science and Higher Education, and the BIOSTRATEG program entitled "GUTFEED_innovative nutrition in sustainable poultry production", No. 267659/7/NCBR/2015.

Conflicts of Interest: The authors declare no conflict of interest. 


\section{References}

1. Churklam, W.; Chaturongakul, S.; Ngamwongsatit, B.; Aunpad, R. The mechanisms of action of carvacrol and its synergism with nisin against Listeria monocytogenes on sliced bologna sausage. Food Control 2020, 108, 106864. [CrossRef]

2. Saad, M.A.; Ombarak, R.A.; Abd Rabou, H.S. Effect of nisin and lysozyme on bacteriological and sensorial quality of pasteurized milk. J. Adv. Vet. Anim. Res. 2019, 6, 403-408. [CrossRef] [PubMed]

3. Gokoglu, N. Novel natural food preservatives and applications in seafood preservation: A review. J. Sci. Food Agric. 2019, 99, 2068-2077. [CrossRef] [PubMed]

4. Lopetuso, L.R.; Giorgio, M.E.; Saviano, A.; Scaldaferri, F.; Gasbarrini, A.; Cammarota, G. Bacteriocins and Bacteriophages: Therapeutic Weapons for Gastrointestinal Diseases? Int. J. Mol. Sci. 2019, 20, 183. [CrossRef]

5. Chikindas, M.L.; Weeks, R.; Drider, D.; Chistyakov, V.A.; Dicks, L.M.T. Functions and emerging applications of bacteriocins. Curr. Opin. Biotechnol. 2018, 49, 23-28. [CrossRef]

6. Bédard, F.; Hammami, R.; Zirah, S.; Rebuffat, S.; Fliss, I.; Biron, E. Synthesis, antimicrobial activity and conformational analysis of the class Ila bacteriocin pediocin PA-1 and analogs thereof. Sci. Rep. 2018, 8, 9029. [CrossRef]

7. Juturu, V.; Wu, J.C. Microbial production of bacteriocins: Latest research development and applications. Biotechnol. Adv. 2018, 36, 2187-2200. [CrossRef]

8. Field, D.; Blake, T.; Mathur, H.; O'Connor, P.M.; Cotter, P.D.; Paul Ross, R.; Hill, C. Bioengineering nisin to overcome the nisin resistance protein. Mol. Microbiol. 2019, 111, 717-731. [CrossRef]

9. Józefiak, D.; Sip, A. Bacteriocins in poultry nutrition-A review. Ann. Anim. Sci. 2013, 13, 449-462. [CrossRef]

10. Register, F. Nisin preparation: Affirmation of GRAS status as a direct human food ingredient. Fed. Regist. 1988, 53, 11247-11251.

11. EEC. Commission Directive 83/463/EEC; E.E.C: Luxembourg, 1983.

12. Aguilar, F.; Autrup, H.; Barlow, S.; Castle, L.; Crebelli, R.; Dekant, W.; Engel, K.-H.; Gontard, N.; Gott, D.; Grilli, S. Opinion of the Scientific Panel on Food Additives, Flavourings, Processing Aids and Materials in Contact with Food on the safety in use of nisin as a food additive in an additional category of liquid eggs and on the safety of nisin produced using a modifi. EFSA J. 2006, 4, 314.

13. Chollet, E.; Sebti, I.; Martial-Gros, A.; Degraeve, P. Nisin preliminary study as a potential preservative for sliced ripened cheese: $\mathrm{NaCl}$, fat and enzymes influence on nisin concentration and its antimicrobial activity. Food Control 2008, 19, 982-989. [CrossRef]

14. Rameshkumar, N.; Govindarajan, R.K.; Krishnan, M.; Kayalvizhi, N. Scope of Bacteriocins as a Viable Alternative to the Traditional Antibiotics. Adv. Plants Agric. Res. 2016, 5, 1-3.

15. Kierończyk, B.; Sassek, M.; Pruszyńska-Oszmałek, E.; Kolodziejski, P.; Rawski, M.; Światkiewicz, S.; Józefiak, D. The physiological response of broiler chickens to the dietary supplementation of the bacteriocin nisin and ionophore coccidiostats. Poult. Sci. 2017, 96, 4026-4037. [CrossRef]

16. Kierończyk, B.; Pruszyńska-Oszmałek, E.; Świątkiewicz, S.; Rawski, M.; Długosz, J.; Engberg, E.M.; Józefiak, D. The nisin improves broiler chicken growth performance and interacts with salinomycin in terms of gastrointestinal tract microbiota composition. J. Anim. Feed Sci. 2016, 25, 309-316. [CrossRef]

17. Bernbom, N.; Licht, T.R.; Brogren, C.-H.; Jelle, B.; Johansen, A.H.; Badiola, I.; Vogensen, F.K.; Nørrung, B. Effects of Lactococcus lactis on composition of intestinal microbiota: Role of nisin. Appl. Environ. Microbiol. 2006, 72, 239-244. [CrossRef]

18. Santoso, B.; Mwenya, B.; Sar, C.; Takahashi, J. Ruminal fermentation and nitrogen metabolism in sheep fed a silage-based diet supplemented with Yucca schidigera or Y. schidigera and nisin. Anim. Feed Sci. Technol. 2006, 129, 187-195. [CrossRef]

19. Van Staden, D.A.; Brand, A.M.; Endo, A.; Dicks, L.M.T. Nisin F, intraperitoneally injected, may have a stabilizing effect on the bacterial population in the gastro-intestinal tract, as determined in a preliminary study with mice as model. Lett. Appl. Microbiol. 2011, 53, 198-201. [CrossRef]

20. Lauková, A.; Chrastinová, L'.; Plachá, I.; Kandričáková, A.; Szabóová, R.; Strompfová, V.; Chrenková, M.; Čobanová, K.; Žitňan, R. Beneficial Effect of Lantibiotic Nisin in Rabbit Husbandry. Probiotics Antimicrob. Proteins 2014, 6, 41-46. [CrossRef] 
21. Gough, R.; O'Connor, P.M.; Rea, M.C.; Gómez-Sala, B.; Miao, S.; Hill, C.; Brodkorb, A. Simulated gastrointestinal digestion of nisin and interaction between nisin and bile. LWT Food Sci. Technol. 2017, 86, 530-537. [CrossRef]

22. Chan, W.C.; Leyland, M.; Clark, J.; Dodd, H.M.; Lian, L.-Y.; Gasson, M.J.; Bycroft, B.W.; Roberts, G.C.K. Structure-activity relationships in the peptide antibiotic nisin: Antibacterial activity of fragments of nisin. FEBS Lett. 1996, 390, 129-132. [CrossRef]

23. Józefiak, D.; Kierończyk, B.; Juśkiewicz, J.; Zduńczyk, Z.; Rawski, M.; Długosz, J.; Sip, A.; Højberg, O. Dietary nisin modulates the gastrointestinal microbial ecology and enhances growth performance of the broiler chickens. PLoS ONE 2013, 8, 1-11. [CrossRef] [PubMed]

24. Onder Ustundag, A.; Ozdogan, M. Effects of bacteriocin and organic acid on growth performance, small intestine histomorphology, and microbiology in Japanese quails (Coturnix coturnix japonica). Trop. Anim. Health Prod. 2019, 51, 2187-2192. [CrossRef] [PubMed]

25. Ozdogan, M.; Ustundag, A.O. Effects of bacteriocin and organic acids on growth performance of Japanese quails. Sci. Pap. Ser. D Anim. Sci. Int. Sess. Sci. Commun. Fac. Anim. Sci. 2015, 58, 164-169.

26. Younes, M.; Aggett, P.; Aguilar, F.; Crebelli, R.; Dusemund, B.; Filipič, M.; Frutos, M.J.; Galtier, P.; Gundert-Remy, U.; Kuhnle, G.G.; et al. Safety of nisin (E 234) as a food additive in the light of new toxicological data and the proposed extension of use. EFSA J. 2017, 15, 5063.

27. Council, N.R. Nutrient Requirements of Poultry: 1994; National Academies Press: Washington, DC, USA, 1994.

28. Drew, M.D.; Syed, N.A.; Goldade, B.G.; Laarveld, B.; Van Kessel, A.G. Effects of dietary protein source and level on intestinal populations of Clostridium perfringens in broiler chickens. Poult. Sci. 2004, 83, 414-420. [CrossRef]

29. Knarreborg, A.; Simon, M.A.; Engberg, R.M.; Jensen, B.B.; Tannock, G.W. Effects of dietary fat source and subtherapeutic levels of antibiotic on the bacterial community in the ileum of broiler chickens at various ages. Appl. Environ. Microbiol. 2002, 68, 5918-5924. [CrossRef]

30. Kaldhusdal, M.; Hofshagen, M.; Løvland, A.; Langstrand, H.; Redhead, K. Necrotic enteritis challenge models with broiler chickens raised on litter: Evaluation of preconditions, Clostridium perfringens strains and outcome variables. FEMS Immunol. Med. Microbiol. 1999, 24, 337-343. [CrossRef]

31. Rawski, M.; Kierończyk, B.; Długosz, J.; Świątkiewicz, S.; Jozefiak, D. Dietary probiotics affect gastrointestinal microbiota, histological structure and shell mineralization in turtles. PLoS ONE 2016, 11, e0147859. [CrossRef]

32. Canibe, N.; Højberg, O.; Badsberg, J.H.; Jensen, B.B. Effect of feeding fermented liquid feed and fermented grain on gastrointestinal ecology and growth performance in piglets. J. Anim. Sci. 2007, 85, 2959-2971. [CrossRef]

33. Sghir, A.; Gramet, G.; Suau, A.; Rochet, V.; Pochart, P.; Dore, J. Quantification of bacterial groups within human fecal flora by oligonucleotide probe hybridization. Appl. Environ. Microbiol. 2000, 66, 2263-2266. [CrossRef] [PubMed]

34. Manz, W.; Amann, R.; Ludwig, W.; Vancanneyt, M.; Schleifer, K.-H. Application of a suite of 16S rRNA-specific oligonucleotide probes designed to investigate bacteria of the phylum cytophaga-flavobacter-bacteroides in the natural environment. Microbiology 1996, 142, 1097-1106. [CrossRef] [PubMed]

35. Franks, A.H.; Harmsen, H.J.M.; Raangs, G.C.; Jansen, G.J.; Schut, F.; Welling, G.W. Variations of bacterial populations in human feces measured by fluorescent in situ hybridization with group-specific $16 \mathrm{~S}$ rRNA-targeted oligonucleotide probes. Appl. Environ. Microbiol. 1998, 64, 3336-3345. [CrossRef] [PubMed]

36. Fallani, M.; Rigottier-Gois, L.; Aguilera, M.; Bridonneau, C.; Collignon, A.; Edwards, C.A.; Corthier, G.; Doré, J. Clostridium difficile and Clostridium perfringens species detected in infant faecal microbiota using 16S rRNA targeted probes. J. Microbiol. Methods 2006, 67, 150-161. [CrossRef] [PubMed]

37. Harmsen, H.J.M.; Elfferich, P.; Schut, F.; Welling, G.W. A 16 S rRNA-targeted probe for detection of lactobacilli and enterococci in faecal samples by fluorescent in situ hybridization. Microb. Ecol. Health Dis. 1999, 11, 3-12.

38. Peinado, M.J.; Ruiz, R.; Echávarri, A.; Rubio, L.A. Garlic derivative propyl propane thiosulfonate is effective against broiler enteropathogens in vivo. Poult. Sci. 2012, 91, 2148-2157. [CrossRef]

39. Wu, J.; Hu, S.; Cao, L. Therapeutic effect of nisin $\mathrm{Z}$ on subclinical mastitis in lactating cows. Antimicrob. Agents Chemother. 2007, 51, 3131-3135. [CrossRef]

40. Cao, L.T.; Wu, J.Q.; Xie, F.; Hu, S.H.; Mo, Y. Efficacy of nisin in treatment of clinical mastitis in lactating dairy cows. J. Dairy Sci. 2007, 90, 3980-3985. [CrossRef] 
41. Tong, Z.; Dong, L.; Zhou, L.; Tao, R.; Ni, L. Nisin inhibits dental caries-associated microorganism in vitro. Peptides 2010, 31, 2003-2008. [CrossRef]

42. Ahmadi, S.; Ghollasi, M.; Hosseini, H.M. The apoptotic impact of nisin as a potent bacteriocin on the colon cancer cells. Microb. Pathog. 2017, 111, 193-197. [CrossRef]

43. Heunis, T.D.J.; Smith, C.; Dicks, L.M.T. Evaluation of a nisin-eluting nanofiber scaffold to treat Staphylococcus aureus-induced skin infections in mice. Antimicrob. Agents Chemother. 2013, 57, 3928-3935. [CrossRef]

44. Jarvis, B.; Mahoney, R.R. Inactivation of nisin by alpha-chymotrypsin. J. Dairy Sci. 1969, 52, $1448-1450$. [CrossRef]

45. Heinemann, B.; Williams, R. Inactivation of nisin by pancreatin. J. Dairy Sci. 1966, 49, 312-314. [CrossRef]

46. Masuda, N. Deconjugation of bile salts by Bacteroides and Clostridium. Microbiol. Immunol. 1981, 25, 1-11. [CrossRef] [PubMed]

47. Klaver, F.A.; Van der Meer, R. The assumed assimilation of cholesterol by Lactobacilli and Bifidobacterium bifidum is due to their bile salt-deconjugating activity. Appl. Environ. Microbiol. 1993, 59, 1120-1124. [CrossRef] [PubMed]

48. Cotter, P.D.; Hill, C.; Ross, R.P. Bacteriocins: Developing innate immunity for food. Nat. Rev. Microbiol. 2005, 3, 777-788. [CrossRef]

49. Kierończyk, B.; Rawski, M.; Długosz, J.; Świątkiewicz, S.; Józefiak, D. Avian crop function-A review. Ann. Anim. Sci. 2016, 16, 653-678. [CrossRef]

50. Yeoman, C.J.; Chia, N.; Jeraldo, P.; Sipos, M.; Goldenfeld, N.D.; White, B.A. The microbiome of the chicken gastrointestinal tract. Anim. Health Res. Rev. 2012, 13, 89-99. [CrossRef]

51. Oakley, B.B.; Lillehoj, H.S.; Kogut, M.H.; Kim, W.K.; Maurer, J.J.; Pedroso, A.; Lee, M.D.; Collett, S.R.; Johnson, T.J.; Cox, N.A. The chicken gastrointestinal microbiome. FEMS Microbiol. Lett. 2014, 360, 100-112. [CrossRef]

52. Józefiak, D.; Rutkowski, A.; Martin, S.A. Carbohydrate fermentation in the avian ceca: A review. Anim. Feed Sci. Technol. 2004, 113, 1-15. [CrossRef]

53. Terada, A.; Hara, H.; Sakamoto, J.; Sato, N.; Takagi, S.; Mitsuoka, T.; Mino, R.; Hara, K.; Fujimori, I.; Yamada, T. Effects of dietary supplementation with lactosucrose (4G- $\beta$-D-Galactosylsucrose) on cecal flora, cecal metabolites, and performance in broiler chickens. Poult. Sci. 1994, 73, 1663-1672. [CrossRef] [PubMed]

54. Zduńczyk, Z.; Jankowski, J.; Rutkowski, A.; Sosnowska, E.; Drażbo, A.; Zduńczyk, P.; Juśkiewicz, J. The composition and enzymatic activity of gut microbiota in laying hens fed diets supplemented with blue lupine seeds. Anim. Feed Sci. Technol. 2014, 191, 57-66. [CrossRef]

55. Corrier, D.E.; Hinton, A., Jr.; Ziprin, R.L.; Beier, R.C.; DeLoach, J.R. Effect of dietary lactose on cecal pH, bacteriostatic volatile fatty acids, and Salmonella typhimurium colonization of broiler chicks. Avian Dis. 1990, 617-625. [CrossRef]

56. Leeson, S.; Namkung, H.; Antongiovanni, M.; Lee, E.H. Effect of butyric acid on the performance and carcass yield of broiler chickens. Poult. Sci. 2005, 84, 1418-1422. [CrossRef]

57. Józefiak, D.; Sip, A.; Rawski, M.; Steiner, T.; Rutkowski, A. The dose response effects of liquid and lyophilized Carnobacterium divergens AS7 bacteriocin on the nutrient retention and performance of broiler chickens. Food Microbiol. 2011, 401-412. [CrossRef]

58. Józefiak, D.; Sip, A.; Rawski, M.; Rutkowski, A.; Kaczmarek, S.; Højberg, O.; Jensen, B.B.; Engberg, R.M. Dietary divercin modifies gastrointestinal microbiota and improves growth performance in broiler chickens. Br. Poult. Sci. 2011, 52, 492-499. [CrossRef]

59. Cole, K.; Farnell, M.B.; Donoghue, A.M.; Stern, N.J.; Svetoch, E.A.; Eruslanov, B.N.; Volodina, L.I.; Kovalev, Y.N.; Perelygin, V.V.; Mitsevich, E.V. Bacteriocins reduce Campylobacter colonization and alter gut morphology in turkey poults. Poult. Sci. 2006, 85, 1570-1575. [CrossRef]

60. Wang, H.; Yu, C.; Hsieh, Y.; Chen, S.; Chen, B.; Chen, C. Effects of albusin B (a bacteriocin) of Ruminococcus albus 7 expressed by yeast on growth performance and intestinal absorption of broiler chickens-its potential role as an alternative to feed antibiotics. J. Sci. Food Agric. 2011, 91, 2338-2343. [CrossRef]

(C) 2020 by the authors. Licensee MDPI, Basel, Switzerland. This article is an open access article distributed under the terms and conditions of the Creative Commons Attribution (CC BY) license (http://creativecommons.org/licenses/by/4.0/). 